\title{
Edvarta Virzas priekšstats par Eduardu Veidenbaumu, papildināts ar Livijas Volkovas atrasto
}

\author{
Anda Kubuliṇa
}

\begin{abstract}
Kopsavilkums
Edvarts Virza Eduardu Veidenbaumu sauc par modernisma aizsācēju un pirmo reālistu latviešu dzejā, izcel viṇa stila skaidrību, lakonismu, no mazotnes kopto tieksmi rast katrai lietai būtību, viņa dzejas filozofiskumu un pilnībā noraida jaunstrāvnieku piedēvēto apzināto revolucionārismu. Nedaudz pārspīlē, kad noraida vācu kultūras ietekmi Veidenbauma pasaules uztverē, ignorēdams faktu Veidenbaums mācỉjās vācu skolās, studēja vāciskajā Tērbatā, kurās apgūstamo zinību gudrību kopums bija galvenokārt vāciski, tāpat no redzesloka izlaida Heines svētīgo ietekmi uz Veidenbauma satīrām, dzejas stilu.
\end{abstract}

Raksturvārdi: satīra, vienkāršība, skaidrība, filozofiskums, klasicisms, matemātiskā pasaules uztvere, antīkā pasaule, ticība.

Eduards Veidenbaums ir viens no nedaudziem rakstniekiem, par kuru Edvarta Virzas pozitīvais viedoklis nemainās mūža garumā, kaut precizējumus gadi, saprotams, iepunktē. Par Rūdolfu Blaumani, Annu Brigaderi - viņam tās ir mūsu literatūras dižākās virsotnes - Edvarta Virzas agro gadu meklējumi, jaunības maksimālisms, idejisko paradigmu main,as vilnis, kurā viņš pats bija iekšā, kādas nekādas kritiskas piezīmes radīja, bet Eduarda Veidenbauma nesaudzīgā skaidrība, vienkāršība, satīras dzirksts, filozofiskums, arī cīn,a par jaunu, savu pasaules uzskatu Edvartu Virzu sajūsmina kā jaunības pārrunās Viktora Eglī̌sa salonā, ${ }^{1}$ tā 1926. gadā poēmas "Dzejas māksla"² rakstǐšanas laikā un saglabājas arī vēlākās apcerēs presē. ${ }^{3}$ Iespējams, tālab, ka bija tuvs paša skarbajam stilam.

1 Netieši atspulgo: Virza, E. Septiņu malēniešu rakstnieku vakars. Brīvā Zeme, 1923, Nr. 240, 26. okt.

2 Virza, E. Raksti. 3. sēj. Sast. A. Kubuliṇa. Rīga: Zinātne, 2009. 377.-396. lpp.

3 Brīvā Zeme, 1924, Nr. 99, 3. maijs; arī 1925, Nr. 294, 12. sept.; tāpat 1927, Nr. 195, 3. sept.; 1939, Nr. 118, 27. maijs. 
Poēmā "Dzejas māksla” par Tērbatas studentu teikts:

Kas dažreiz dzejniekam ir labas dzejas raugs, Teic Edvarts Veidenbaums, tuvs Horācija draugs. Nav viņam priekšteču, viņš vientuḷ̌s laiku maiṇās, Kas dziḷ̌s pie Horāca un nepārejošs daiņās, Tas pantos vienkāršos tam vienkārši top siets. Un dzejā reāli pie mums viņš pirmais triec. Arvienu pārvalda tam prāts ikkatru jūtu, Un māk viņš skaidris būt, bez kā jel seklis kḷūtu. Tāds ir šis dziesminieks, daudz izslavēts un bārts, Pilns slēptiem asumiem un ìss kā sakāmvārds.

Tā pantiem nopietniem gar dabu mazas bažas, Viņš savām domām ņem no tās tik krāsas dažas. ${ }^{4}$

Poēmā Veidenbaums saukts par pārmaiņu laika personību. Tas sakrīt ar Andreja Upīša 1927. gada recenzijas viedokli par Rūdolfa Egles sastādītiem Eduarda Veidenbauma Rakstiem, ${ }^{5}$ bet kopumā - ar Lìvijas Volkovas uzzīmēto Kalāču jaunekl̦a portretu pētījumā "Eduards Veidenbaums". ${ }^{6}$

Tajā kādā vietā teikts: pirms kara (domāti 30. gadi) Veidenbaumam neiznāca neviena izlase, viņš tika noklusēts. Izlases tiešām neiznāca, tās nebija tā laika garā, toties raksti gan parādījās. Tātad nekādas noklusēšanas nebija. To rāda kaut vai viena paša Edvarta Virzas četras dažādos gados publicētas apceres, par Rūdolfa Egles sastādītiem Rakstiem nemaz nerunājot. To, kāpēc no Eduarda Veidenbauma aprūpētājiem pakavēšos tieši pie Edvarta Virzas apcerēm, sevišḳi pēdējās, un Livijas Volkovas pētījuma, nosaka: Edvarta Virzas raksts ir pēdējā publikācija brīvvalsts periodā, tā atceras Eduardu Veidenbaumu, pirms valsts zaudē neatkarību, savukārt Līvijas Volkovas pētījums ir labākais, kas izstrādāts par viṇu padomju okupācijas laikā. Pētnieces atšifrētās stenogrammas precizēja dažus līdz tam nezināmus dzejnieka dzīves, daiḷrades faktus, arī tālab. Viṇas grāmata joprojām ir jaunākā Eduardam Veidenbaumam veltītā zinātniskā monogrāfija, vēl arī tālab. Stenogrammu atšifrējumi līdz ar pētījumiem "Blaumaṇa zelts" (2008), "Rūdolfa Blaumaṇa pašatklāsme" (2017) ir Lìvijas Volkovas paliekošais un nezūdošais devums mūsu literatūrzinātnei, arī tālab.

4 Virza, E. Dzejas māksla: Didaktiska poēma. Grām.: Virza, E. Raksti. 3. sēj., 384. lpp.

5 Upīts, A. Eduarda Veidenbauma dzīve un darbi. Grām.: Upīts, A. Kopoti raksti. 17. sēj. Rīga: Latvijas Valsts izdevniecība, 1951. 450.-458. lpp.

6 Volkova, L. Eduards Veidenbaums. Problēmas, risinājumi, hipotēzes. Rīga: Liesma, 1979. 
Visplašāk Virza par Veidenbaumu izsakās mūža nogales ${ }^{7}$ rakstā "Eduarda Veidenbauma dzeja", ${ }^{8}$ kas tapis 1939. gada maijā, atceroties dzejnieka nāves 47. gadadienu. Nāves gadadienas rakstā uzsvērts Kalāču jaunekḷa lirikas dziļums, savrupība, kas Tērbatas studentu savulaik cēla pāri tā laika latviešu lirikai. Savrupību, dziḷumu bija minējis jau Kārlis Kasparsons nekrologā, ${ }^{9}$ tāpat Edvards Treimanis-Zvārgulis pirmos Kopotos rakstos, ${ }^{10}$ arī Andrejs Upìts jau minētā 1927. gada recenzijā par Rūdolfa Egles sastādītajiem Eduarda Veidenbauma Rakstiem. ${ }^{11}$ Saprotams, arī Egle ${ }^{12}$ dziḷumam pieskaras, apcerot dzejnieka dzīvi un daiḷadi. Tālab šai sakarā līdzīgā Virzas un Volkovas tēze ir pašsaprotama, agrāku gadu aprobēta. Volkova neatkārto Virzu, uz kuru atsaukties padomju gados vina nemaz nedrīkstēja, kaut acīmredzami rakstīto zināja. Par zināšanu vedina domāt Virzas nepiepildītā rosinājuma piesaukšana: "Kāds no Rīgas skaistiem laukumiem velti gaida vina statuju." ${ }^{\prime 3}$

Hronolog̣iski sekojot Virzas precizējumiem Veidenbauma lirikas uztverē, ieraugām: jaunībā vinu aizrāva Kalāču savrupnieka cinna par savu pasaules uzskatu, ${ }^{14}$ pēcāk škitis svarīgi iebilst pret vienpusīgi saprastu dzejnieka protesta

\footnotetext{
${ }^{7}$ Pārspīlēts ir Līvijas Volkovas teikums: "30. gados sāka izveidoties loti raksturīga aina. Šai laikā buržuāziskā Latvijā vairs neiznāca neviena Veidenbauma grāmata, neviens nozīmīgāks darbs par Veidenbaumu, turpretī Padomju Savienībā [..] arvien vairāk sāka pievērsties Veidenbaumam." (Volkova, L. Eduards Veidenbaums, 27. lpp.) Ja atceras, ka viens pats Virza apcer vinuu darbā "Dzejas māksla: Didaktiskā poēma", min rakstā par Edvardu TreimaniZvārguli, izceldams abiem draugiem kopīgo (Brīvā Zeme, 1924, Nr. 99, 3. maijs), pieskaras dzejniekam, runādams par Rūdolfa Egles apceri un par dzejnieka brāḷa Kārḷa dzeju (Brìvā Zeme, 1925, Nr. 204, 12. sept.), arī kad vērtē Rūdolfa Egles sastādītos Veidenbauma Rakstus (Brìvā Zeme, 1927, Nr. 195, 3. sept.), tāpat 1939. gadā apcerot viña dzeju, tad diezin vai var teikt, ka nerunāja (kaut saprotu - šādu formulējumu prasīja drakoniskais padomju laiks, un tāpēc pārmetums ir formāls, neapšaubot pētnieces pamatspriedumus). ${ }^{8}$ Brīvā Zeme, 1939, Nr. 118, 27. maijs. - Veidenbauma atcere notiek maijā, ko, stingri ņemot, var skatīt kā Virzas slēptu vēršanos pret Ulmani: 30. gadu otrā pusē viņa jūsma par vadoni plok, kaut tas netiek afišēts. Vien 1939. gada Trešās Lieldienās sacerētā "Baigā vasarā" (veltīts Veronikai Strēlertei) aiz piesauktās nodevības ar lielu ticamību varētu slēpties nevis tā vai cita dāma, bet arī vadonis. ("[..] ja kāds apgalvo, ka Virza bijis nez kāds "galma dzejnieks", tad tas ir galīgi greizi teikts. Virza dažu labu reizi bija ar tā saucamo "galmu" konfliktā un 1939. gada rudenī - gan ne literāru jautājumu dēḷ - tik smagā konfliktā, ka viņam pavēlēja dažas nedēlas atstāt Rīgu un uzturēties savās lauku mājās Billītēs." (Rudzītis, J. Raksti. Vesterosa: Ziemeḷblāzma, 1977. 171. lpp.))

${ }^{9}$ Dienas Lapa, 1892, Nr. 108, 13. jūn., 3. lpp. sadaḷā "Iekšzemes ziṇas" ievietots sludinājums par Eduarda Veidenbauma nāvi; Dienas Lapa, 1892, Nr. 114, 22. maijs, 2. lpp. sadaḷā "Iekšzemes ziņas" no Mūrmuižas atrodam ziņu ar Eduarda Veidenbauma bēru norises aprakstu, ko parakstījis anonīms - m -; Dienas Lapa, 1892, Nr. 134, 16. jūn. ievadā K. Siguldieša [Kasparsona] izvērsts nekrologs "Eduards Veidenbaums".

${ }^{10}$ Veidenbaums, E. Kopoti raksti 6 sējumos. Valmiera, 1907-1909.

${ }^{11}$ Upìts, A. Kopoti raksti. 17. sēj. Rīga: Latvijas Valsts izdevniecība, 1951. 450.-458. lpp.

${ }^{12}$ Eduarda Veidenbauma raksti. Sast. R. Egle. Cēsis; Rīga: O. Jēpes apgāds, 1926.

${ }^{13}$ Virza, E. Eduarda Veidenbauma dzeja. Brìvā Zeme, 1939, Nr. 118, 27. maijs.

${ }^{14}$ Atgādināja paša centienus pēc jauniem dzejas apvāršņiem - sk.: Septiņu malēniešu rakstnieku vakars. Brivō Zeme, 1923, Nr. 240, 26. okt.
} 
garu, ${ }^{15}$ vēl vēlāk nozìmīgs licies vina skaidrais idejas izklāsts ar nobeiguma pilnskanīgo akordu, griezīgais stils, pilns slēptiem asumiem, un vienādin minētā antīkās kultūras klātbūtne, sevišḳi Horācija svētīgie impulsi jaunekḷa tikumiskai krietnībai, vina ironiski satīriskai, racionālai dzejas frāzei. ${ }^{16}$

Veidenbauma savrupību, strupo lakonismu Virza raksturo vārdiem:

Viṇam bijušas īpašības, kas to atdala no citiem. Tās bijušas tik savādas, ka to dēḷ vieni viṇu pieskaitījuši pavisam sekliem ikdienas gariem, bet citi atkal visdziḷākiem. Pirmos maldinājusi viņa dzejas nesaudzīgā skaidrība, kurai nav līdzības ne ar vienu mūsu dzejnieku. [..] Pie mums iesakn,ojies uzskats, ka skaidrība ar dzilumu nav savienojama. Veidenbaums ir koncentrēts it kā kāda Larošfuko sentence, kurš ìss it kā sakāmvārds. Tāpēc daudzi viṇa panti tiek citēti visādos gadījumos, bet neviens nezina, kas ir bijis to autors. ${ }^{17}$

Koncentrēto lakonismu Virza saista ar Horācija mācībstundām:

Viņš [Veidenbaums] sekojis Horācijam līdzi uz Olimpu [..], [sekojis] vienam no visdzilāākiem Eiropas lirikiem. Savu iedzimti filozofisko, pašu parādību būtību tverošo prātu viņš pie tā ir skolojis un caur to ir realizējies latīṇu zelta laikmeta dzejas brīnums modernā latviešu dzejā. ${ }^{18}$

Virza Veidenbaumu tātad uzskata par pirmo reālistu un modernistu latviešu lirikā.

Par to, ka Virzam pie sirds gāja Kalāču studenta loǵiskā skaidrība, nebūtu ko brīnīties: arī pašam tā piemita, kā atzīmējuši laikabiedri. ${ }^{19}$ Augsto, 1939. gadā formulēto Virzas vērtējumu Volkova it kā atkārto, taču, minēdama filozofisko šķautni, ${ }^{20}$ konkretizē to pilnīgi citādi - sasaista ar Veidenbauma kaislo mīlestību uz matemātiku, ar viņa matemātisko pasaules uztveri, kas, viņasprāt, iekopa ne vien lakonismu, bet arī radināja meklēt katrai lietai būtību. Būtības tieša nosaukšana, ko Kalāču puika mācās jau zēnībā, savā vaḷā veidodams herbārijus, ir tā asā žilete, ar ko, Virzas ieskatā, dzejnieks no sevis nogrieza jūtelīgo, aklo vācu gleznainuma tradīciju, kāda valdīja tā laika latviešu lirikā. Pie 19. gadsimta 80. gadu

15 "Bet, kamēr Veidenbaums savu dzeju caur filozofiju un klasiskās literatūras studijām noveda līdz prātnieciskam dziḷmam, Treimanis padevās vairāk sava laika iespaidiem." (Brīvā Zeme, 1924, Nr. 99, 3. maijs)

${ }^{16}$ Virza, E. Eduarda Veidenbauma dzeja. Brīvā Zeme, 1939, Nr. 118, 27. maijs.

${ }^{17}$ Turpat.

18 Turpat.

${ }^{19}$ Par to: Cedriņš, V. Skaidrības dzejnieks. Brīvā Zeme, 1939, Nr. 168, 29. jūl.

20 "Eduarda Veidenbauma dzeja bija pirmā filozofiskās domas izpausme latviešu literatūrā." (Volkova, L. Kā spārnos skrien stundas, skrien skaudīgais laiks. Grām.: Veidenbaums, E. Brīvïbas cēlajais gars. Rīga: Liesma, 1978. 5. lpp.) 
latviešu dzejas jūtelības, aklām gleznām vainīgi Virzam rādījās vāci. Šḳirdams Veidenbaumu no vāciskā, viņš pilnībā ignorē faktu, ka Tērbatas students latviski mācījās tikai gadu Cēsu draudzes skolā, pāris gadus Cēsu apriṇķa skolā, kamēr Rīgas guberņas ǵimnāzijā, Tērbatā Universitātē mācības un grāmatas bija tikai vāciski. Viṇš brīvi pārvaldīja vācu valodu. Vāciskuma jautājumā Virza kḷūst galējs - noklusē Heinriha Heines (to savukārt izceḷ Volkova) un citu vācu dzejnieku atbalsis viņa poētikā. Uz to, tāpat nacionālo tradīciju - Ausekḷa kopto satīras sliedi, kas dokumentēta tērbatnieka stenogrammās -, pamatoti norāda Volkova, kamēr Virza min vienīgi tautasdziesmu un antīkā ${ }^{21}$ mantojuma atbalsis, secinādams: Veidenbaums turpina Jura Alunāna ${ }^{22}$ racionālo un nevis Ausekḷa mitologisko tradīciju. Tātad - poētisko sakņojumu redz citur nekā Volkova. Ja neaizmirst, ka Virzas ieskatā Veidenbauma dižākais pienesums latviešu dzejai ir "augsta, Moljēra mērogos ieturēta satīras žanra iedibināšana", ${ }^{23}$ tad Heines neminēšana neviḷus prātā atsauc vēl dažus retus, selektīvus Virzas kultūras sakaru interpretējumus - pēc Pirmā pasaules kara arī krievu tradīcijas noraidīšanu. Atškiiras arī Virzas un Volkovas traktējumi skaidrības un vienkāršības jautājumā: Virza tās redz izaugam no tautasdziesmām, taču visvairāk no tā, ka Veidenbaums tēlus "neiestāda" dabas aprišu mežg̀īnēs. Viṇam būtība, "viss izriet no cilvēka prāta spēku spēles, to analīzes. Dzejā Veidenbaums patur savu no dabas neatkarīgo, virsrocīgo stāvokli." ${ }^{4}$ Viṇa "priekšrocība ir nevis krāsas, bet zīmējums. Viṇam ir neaizplīvurots skats uz visām lietām", ${ }^{25}$ tālab viṇa vārds ir gan aktīvs, gan konkrēts reizē. Rituma mainu mirklis ir vienīgais, ko cilvēks, pēc Veidenbauma, spēj satvert. Virzas ieskatā - virspusēji gleznaina dabas redzējuma izstumšana no tēla noteica Kalāču studenta koncentrēto, skaidro lakonismu: izteiksme auga kopā ar domu, pārdzīvojumu, ko viņš risināja, to neaizsedza krāsaini trieptas ārējības impresijas. Uz nesaudzīgu skaidrību dzejnieku spieda, Virzasprāt, arī īsi atmērītais mūža laiks, ko jauneklis sevī nesa.

Varētu gaidīt: 1939. gada pozitīvisma gaisotnē Virza apies Veidenbauma svabadā gara saucienu. Un tomēr viṇš Veidenbaumu par tādu saucēju min gan, pat

21 "Veidenbaums, šis antiskās [antīkās] erudīcijas pilnais dzejnieks, ir mūsu labākais Horācija atdzejotājs. Lai gan līdz šai dienai šis latīṇu autors ir daudzu tulkots, neviens nesasniedz Veidenbauma tulkojumu svaru, vienkāršỉbu un skaidrību." (Virza, E. Eduarda Veidenbauma dzeja. Brīvā Zeme, 1939, Nr. 118, 27. maijs)

${ }^{22}$ Arī Juris Alunāns savulaik tulkoja Horāciju.

23 "Viens no Eduarda Veidenbauma lieliem nopelniem ir mākslinieciskās satīras ievešana mūsu dzejā. Līdz tam satīru uzskatīja par zemāku dzejas veidu, bet Veidenbaums ar savām nedaudzām satīrām tai ierādīja goda vietu mūsu dzejas sistēmā. Veidenbauma satīras negriežas pret atsevišķām personām, bet viņš vēršas pret atsevišķām cilvēka dabas l̦autām tieksmēm, bieži vien sakopotām vienā cilvēkā. Vēl līdz šim mūsu dzejā nav labākas satīras par līdēju, ko skaidri un asi noraksturojis Veidenbaums." (Virza, E. Eduarda Veidenbauma dzeja. Brīvā Zeme, 1939, Nr. 118, 27. maijs)

${ }^{24}$ Virza, E. Eduarda Veidenbauma dzeja. Brīvā Zeme, 1939, Nr. 118, 27. maijs.

${ }^{25}$ Turpat. 
norāda, ka "ḷaužu vērību pie viṇa saistīja sabiedriska protesta balss", ${ }^{26}$ turklāt šo minējumu Virza veica vērienīgi, bez atsauces uz jaunstrāvnieku sašaurināti škiririsko logatu. ${ }^{27}$ Arī protestā, pēc Virzas domām, Veidenbaums stāv savrup:

Viņš bija viens no tiem, kas iededzināja protesta garu pret vācu un krievu patvaldību. [..] Neko nepārspīlējot, var sacīt, ka vinš̌ bija lielākais 1905. gada notikumu iezvanītājs un viņa nacionāli revolucionārā balss latviešu gājienā uz pilnīgu brīvi skanējusi nenorimdama. ${ }^{28}$

Arī padomju laikā, kā atceros no skolas gadiem Sabilē, Virzam brīvības gars pastāv kā tāds, kā patstāvīgs gara fenomens; viņš to saprot līdzīgi Maksam Štirneram $^{29}$ un škirir no marksisma škiiriskās pozīcijas:

Nekāds revolucionārs šis dzejnieks nav bijis. Viṇa protesta garam divi pamati - latviskais un individuāli filozofiskais. Kā īsts latvietis, viņš nevarēja nenīst krievu patvaldību un vācu baronus - nepanesami bija pinekḷi, ko Krievija uzlika ikvienai īstai personībai [..]. ${ }^{30}$

Veidenbauma protestu īpašu Virzas acīs dara mūžības dimensija. Šo šķautni viņš redz piegulam dzīvībai, kustībai, brīvības ilgu gara izpausmēm ne vien cilvēkā, bet arī dabā, kosmosā. ${ }^{31}$ Tālab no Kalāčiem atskanējušais sauciens Virzam rādās filozofiski padziḷināts, nevis virspusējs, sociāli sīkumains: "[V]iņš problēmām tuvojas kā filozofs, ne kā sociāls aǵitators." ${ }^{32}$ Veidenbauma brīvības sauciens Virzas ieskatā vispārina cilvēka visaptverošo saiti ar pasauli, tieši tālab viṇa dzeja ir pārdzīvojusi savu laiku. Saite Veidenbaumam ir objektīvi plaša, taču ierobežota. Gan ne sociāli. Tās ierobežotību noteic fatālisms, kas izaug no nespējas izziṇā vienlaikus aptvert visu kosmosu. Fatālisms nepārejošs kḷūst tad, kad prāts saskaras ar kosmisko ritējumu, ar dievības garu. Tieši šì Tērbatas studenta redzējuma skaldne, tās klasiskie mērogi, dziḷums telpā uzrunā atšķirīgu laikmetu cilvēkus, paaudzes. ${ }^{33}$ Virzas interpretācija te no Volkovas atškiras ar brīvības gara mēroga aprisēm, to citādo apjēgsmi. Gribas teikt - par labu Virzam. Ar saudzējošu

${ }^{26}$ Virza, E. Eduarda Veidenbauma dzeja. Brīvā Zeme, 1939, Nr. 118, 27. maijs.

${ }^{27}$ Tātad neuzskatīdams Veidenbaumu par jaunstrāvnieku, kā to dara jaunais 30. gadu kritikis Jānis Rudzītis.

${ }^{28}$ Virza, E. Eduarda Veidenbauma dzeja. Brīvā Zeme, 1939, Nr. 118, 27. maijs.

${ }^{29}$ Tuvāk sk. Skaidrītes Lasmanes rakstu šajā krājumā "Nepabeigtais Veidenbauma kanons literārajā atmiṇā", sevišḳi sadaḷu "Anarhisms Veidenbauma dumpinieciskajā kanonā".

${ }^{30}$ Virza, E. Eduarda Veidenbauma dzeja. Brīvā Zeme, 1939, Nr. 118, 27. maijs.

31 "Bet kuram asajā gaisma spīd, / Prāts kam visapkārt skatīt spiež tāli, - / Zemē no debesīm dievi krīt, / Putekḷos izirst ideāli. / [..] / Neprātību neviens nevar saukt / To, ko cilvēks sev izvēlas brīvi."

${ }^{32}$ Virza, E. Eduarda Veidenbauma dzeja. Brīvā Zeme, 1939, Nr. 118, 27. maijs.

33 "Dziḷ̆š domātājs, viņš redz dzīvē un Visumā vienu un to pašu dzīvības garu darbojamies: "Tumšajā dzilumā spīguḷo zvaigznes, / Mūžīgā kārtībā kustas to bars, / Cilvēka likteņa drūmajos viḷ,nos / Valda bez rimšanas dzīvības gars."' (Virza, E. Eduarda Veidenbauma dzeja. Brīvā Zeme, 1939, Nr. 118, 27. maijs) 
piebildi par Volkovu: Virza savējo formulēja salīdzinoši demokrātiskā Latvijā, Volkovai marksisma akcentu pievilkt spieda padomju okupācijas apstākḷi. Viṇa darīja to iespējami minimāli. ${ }^{34}$

Tāpat bez saukliem Volkova piemin: Veidenbaums ir sava laika cilvēks, audzis religíozā tēva, vectēva paspārnē, viṇa dzejoḷos reliǵiozu sajutumu klātesme tālab neizbēgama. Jo visi, arī Veidenbaums, nāk no savas bērnības. Bet epitets "svētos" ("svētos liekuḷus - garīdzniekus") vērsts pret cilvēcē mūžam neiznīdējamo liekulību, svētulību kā tādu un ne tik daudz pret garīdzniecību vispār: institūcija nevar atbildēt par tās kalpotāju zemiskumu. Padomju laikā šāds Volkovas atzinums bija vairāk nekā dūšīgs, kaut tieši neteica: Veidenbaums bija ticīgs cilvēks, kas ik svētdienu gāja baznīcā. Jo ar to iešanu baznīcā jau arī bija, kā bija. Par reliǵisko jūtu klātesmi viṇa dzejā runā epiteti dievības gars, dievības gaišums, dievīgā acs, debesu vara, debesu valstība, pasaules arhitekts, vecais Dievs, Dieva prāts un citi, arī biežais kristīgo priekšstatu Dievs, elle, grēks, paradīze lietojums un dzejoḷi, kas interpretē Bībeles sižetus, kā "Ar šis zemes vareniem kopā tu varēji būt", "Gods Dievam augstībā", "Rau, svētku eglīte tik koši" un citi. Šos dzejoḷus padomjlaika izlases neizcēla, tiesa, arī nenobēdzināja. Un neizceldamas pēckara paaudzēm nošķieba priekšstatu par dzejnieku varai vēlamā virzienā: zuda pasaules veselums, izspīlējās 19. un 20. gadsimta mijas sociālās netaisnības kliedziens. Filozofisko skaldni gan dzēst vienalga nespēja. Arī tālab padomju laikos Veidenbaums turējās kulta figūras statusā, kuru pirms kara stabilizēja ne tikai Andreja Upīša, sociāldemokrātu un Krievijas latviešu regulārie dzejnieka piesaukumi, bet arī Virzas 20.-30. gadu apceres. Varai vēlamo nošķiebumu veicināja tas, ka gan Edvarda Treimaņa, gan Rūdolfa Egles sastādītie Raksti, kur sociālā šķautne skan krietni klusāk nekā pēckara izlasēs, pieejami bija vienīgi lielajās bibliotēkās Rīgā, nevis katrā mazpilsētas vai skolas grāmatu krātuvē. Volkovas minējums par reliǵiskām jautām, pretrunību 70. gadu otrā pusē jundīja papildu interesi ${ }^{35}$ par dzejnieka šaubu raksturu, liekot uzdurties uz kristīgiem sižetiem pat Svētos Rakstus nepārzinošiem ateistiem tādās rindās kā:

Ar šìs zemes vareniem kopā tu varēji būt Un valdìt un kārumus baudīt un līksmot ikdienas, Bet cilvēku bēdas un trūkumus sirds tevīm jūt, Un tumsības slogus un nastas ikvienas.

Un, tēvijas neatzīts, svešumā dodies tu tāḷi Un sludini taisnību, māci, ka cilvēki brāḷi, Ka pasaules mantas nespēj mums mierināt prāta, Ka ticības trūkst un mīlestīb’ sirdī nav krāta.

${ }^{34}$ Padomiskums vīd, runājot par Aleksandru Daugi, bet Dauge, tāpat kā Virza, padomju laikos bija publiski neminamas personas. Tas, ka Volkova Daugi, vienu no tuvākiem Veidenbauma studiju biedriem, tomēr min, ir varoṇdarbs.

${ }^{35}$ Domāju, arī tālab tik daudz 60. gadu beigu un 70. gadu dzejā minēts Veidenbaums pats, viņa tēli, rindas (Knuts Skujenieks, Jānis Peters, Māris Čaklais, Uldis Bērziņš, Pēters Brūveris un citi, ko daḷēji dokumentē Intas Čaklās sastādītā izlase: Veidenbaums, E. Dzeja. Rìga: Nordik, 2005). 
Tu priekus tiem nesi, kas tumsībā, grūtībā smaka,

Tu vārgulu sagrauztām sirdīm bij dzīvības aka,

Tu cilvēci sildīji garīgās verdzības salnā,

Un cilvēce atmaksu deva tev - Golgātas kalnā,

kur portretēts pusnoliegtās religijas personāžs Kristus - kristīgas līdzjūtības, žēlsirdības simbols. Līdzīgi kā dzejolis "Gods Dievam augstībā" atgādināja par luterisko liturgijiu. Virza, apcerot Veidenbauma lirisko mantojumu, saprotams, vispirms atcerējās ap 1906. gadu presē lasītos dzejoḷus, pēc tam studēja Treimaṇa-Zvārguḷa, Rūdolfa Egles sastādītos Rakstus. ${ }^{36}$ Pats būdams reliǵiozi jūtīgs, Virza Kalāču jaunekḷa pasaules visaptveri saprata kā pašsaprotamu, bet Cēsu skolotāja Bēma, vēlāk Štirnera sēto šaubu sēklu pieskaitīja jaunības nervozajām juton,ām, dzenājoties pēc sava pasaules uzskata. Arī tālab reliǵgiozitāti Virza savās apcerēs par dzejnieku īpaši neizcēla. Toties stingri iebilda pret jaunstrāvnieku marksistisko vienpusību. Volkova jaunstrāvniekiem neiebilst; strādādama padomju laikos, par tendenciozitāti izlasēs saprotamu iemeslu dēḷ klusē, dzejnieka reliğiskās noskaņas min bez jūsmas. ${ }^{37}$ Ļoti svarīgs bija (un paliek) viņas izceltais, Teodora Zeiferta 1898. gadā pirmoreiz piesauktais Veidenbauma šaubu gars, ${ }^{38}$ kurā pētniece redz saskari ar trağisko, tas ir, katarsi. Virza šaubu gara izsviesto katarsi neapcer. Iespējams, te, ja kāds grib, var saskatīt laikmeta, tas ir, 30. gadu oficiālā pozitīvisma, zīmogu. Otrs iemesls neizcelšanai bija, manuprāt, krietni ticamāks - atsaukties uz Veidenbauma pretrunības traǵiku Virzam nozīmētu publiski piekrist Upītim, ${ }^{39}$ ko neḷāva abu savstarpējās attiecības, lai gan Kalāču students viniiem abiem bija vienādi liela un iespaidīga personība latviešu literatūrā.

No teiktā izriet: Virzas apceres punktē Veidenbauma formu, stilu - prāta pārsvaru pār dabu un jūtām, zīmējuma un nevis krāsu dominanti, izcel noslēdzošā akorda vietu viņa stilā, sauc viņu par pirmo ìsto reālisma un modernisma pārstāvi latviešu dzejā ar asu, šķautņainu frāzi. Arī Volkova tirzā Veidenbauma formu, detalizēti pievērsdamās ritma maiņām viena dzejoḷa robežās. Ritma maiņas, viņasprāt, ir Veidenbauma satīriskā stila paņēmiens. Viṇas analīzes ir precīzas, izvērstas, argumentētas, pamato dzejnieka šokējošo novitāti: viņ̌̌ pirmais latviešu dzejā atmet pieturzīmes, tā izceldams radošā procesa nepārtrauktību, pirmais

\footnotetext{
${ }^{36}$ Rūdolfa Egles sakārtotos Rakstus pat recenzēja, tāpat kā Kārḷa Veidenbauma dzeju.

${ }^{37}$ Volkova, L. Eduards Veidenbaums, 231. lpp.

38 "Pilns šaubu un jautājumu, viṇš kā meteors parādījās pie latviešu literāriskām debesīm, lai uzliesmotu un pazustu, bet lai iemestu elektrisku dzirksteli. Veidenbaums bija šaubu gars, stiprs, tik stiprs, ka viņ̌s sakustināja stabus, lai māja viņam krìt vai uz galvas. Viņa ieroči bija asiņaina satīra un skaudīga ironija, kurus viņ̧ prata lietot ar šausmīgu veiksmi, nosodīdams visu lieku un riebīgu, no viņa labvēlīgā ideāla raugoties. Viņa literāriski vēsturīgā paliekamā nozīme ir šaubas, tās šaubas, kas sakustināja prātus, lika šaubīties par citiem, kas sen bija apzīmēti par nešaubīgiem." (Zeiferts, T. Jaunākā latviešu lirika. Dienas Lapa, 1898, Nr. 155, 24. dec.)

39 "Kā visi lielie starplaikmetu cilvēki, tā ir komplicēta, problemātiska, dzīvē dziḷi traǵiska personība, pretmetos veidota, ar grūti atminamu un apgaismojamu raksturu." (Upīts, A. Eduarda Veidenbauma dzīve un darbi. Grām.: Upīts, A. Kopoti raksti. 17. sēj., 450.-451. lpp.)
} 
tīro atskaņu vietā pāriet uz asonansēm, tas ir, saknes atskaņām rindu iekšienē. Volkova rāda Veidenbauma inteliǵento, mūsdienām neparasto humānismu, klāstot lauku ḷaudīm nezināmos īpašuma jautājumus skaidros, Cicerona izkoptos periodos. ${ }^{40}$ Un tomēr - Virzas raksts, kaut līdz tik precīzām analīzēm nenonāk, izdara vairāk - minot Veidenbauma ienestā klasicisma mērogus viņa satīrās, Virza atgādina - laikmeta tēlotās parādības skatāmas mūžỉbas perspektīvā. Tā ir l,oti tālu vertikāḷu ieraudzišana un tuvināšana, ja Kalāču jaunekli noliek līdzās Eiropas klasicisma dižgaram Moljēram, redzot abus līdzīgi graizām liekulību: viens "Tartifā", otrs līdēja tēlā. Virza to pamana tālab, ka sajuta Tērbatas jaunekli esam lasījušu frančus oriǵinālā. Ar to nav noliegta Volkovas konkrēto analǐžu vērte. 20. gadsimta 70. gados šo analǐžu nozīme sabiedrībā bija patiešām vairāk nekā liela, saslēdzās ar tolaik Rīgas zinātniskā domā ienākošā strukturālisma pieeju. Tomēr literatūras tālākai attīstībai, stabilam kopskatam, manuprāt, svarīgāks joprojām paliek Virzas piesauktais klasicisma uzstādīto mērogu aktualizējums. Tā, protams, paliek vēlme, ne pārmetums Volkovai: padomju smacenī piesaukt Virzas atklāto nozīmētu sevi iznīcināt. Noslēguma piebilde: pētniece rakstīja plašu monogrāfiju, Virza - avīžu rakstus, tātad konkrēto analī̌̌u iespējas katram no viņiem bija atšķirīgas.

\section{Edvarts Virza's vision of Eduards Veidenbaums, as supplemented by the findings of Livija Volkova}

\section{Anda Kubuliṇa}

Edvarts Virza calls Eduards Veidenbaums the originator of modernism and the first realist in Latvian poetry, and highlights the clarity of his style, laconicism, the tendency cultivated from an early age to find the essence of everything, the philosophical nature of his poetry. He completely rejects the deliberate revolutionarism attributed to the New Currentists (members of Latvian Socialist movement 1890-1905). Moreover, Virza rejects the influence of German culture on Veidenbaums's worldview, thus ignoring the fact that Veidenbaums studied in German schools, especially in Dorpat, where the knowledge was mostly acquired in German. Virza also leaves unnoticed Heine's blessed influence on Veidenbaums's satire.

Keywords: satire, simplicity, clarity, philosophy, classicism, mathematical perception of the world, ancient world, faith.

${ }^{40}$ Te Volkova netieši Veidenbaumu tuvina Rūdolfam Blaumanim, kurš arī savus negatīvos tēlus nepazemoja ar kroplu valodu. Tik augsta tolaik bija inteliǵentu cieņa pret jebkuru cilvēku: "[F]ormas ziṇā tā ir unikāla parādība visā latviešu kultūras vēsturē. Kur ir mums vēl otrs populārzinātnisks raksts, kas veidots kā runa pēc visiem klasiskajiem oratora mākslas principiem? Gara tumsībā nomāktais latviešu zemes strādnieks - tieši viņam adresēts šis brīvā gara atmodas aicinājums - tiek uzrunāts Cicerona stilā!” (Volkova, L. Eduards Veidenbaums, 73. lpp. 